\title{
Are there sufficient diagnostic criteria for bronchial atypical carcinoid? A case report of bronchial pigmented spindle cell carcinoid with a review of the literature
}

\section{Czy są całkowicie wystarczające kryteria diagnostyczne dla bronchial atypical carcinoid? Przypadek bronchial spindle cell pigmented carcinoid. Przegląd piśmiennictwa}

\author{
Piotr Lewitowicz¹, Agata A. Horecka-Lewitowicz² \\ ${ }^{1}$ Department of Pathology, Institute of Nursing and Obstetrics, Faculty of Health Sciences, Jan Kochanowski University, Kielce, Poland \\ Head of Department: Prof. Anna Nasierowska-Guttmejer MD, PhD \\ ${ }^{2}$ Department of Public Health, Institute of Public Health, Faculty of Health Sciences, Jan Kochanowski University, Kielce, Poland \\ Head of Department: Prof. Monika Szpringer MD, PhD
}

Key words: bronchial carcinoid, spindle cell carcinoid, atypical carcinoid.

Słowa kluczowe: rakowiak, atypowy rakowiak, rakowiak wrzecionowatokomórkowy.

\begin{abstract}
Here we present a case of a 42-year-old female patient with pigmented spindle cell variant of bronchial carcinoid. The aim of this study was not only to record a rare variant of this tumour but also to highlight the differences in diagnostic criteria of gastrointestinal and bronchopulmonary-thymic neuroendocrine neoplasms. Ki-67 index is a discriminating factor in differential diagnosis between gastrointestinal neuroendocrine tumours (NETs) and, only optionally, in bronchopulmonary-thymic tumours. Since diagnosis is currently based on mitotic activity, optionally Ki-67 index and tumour necrosis, a rare variant of NET, spindle cell carcinoids with cellular atypia could be potential pitfalls for diagnostic controversies or mistakes. Nevertheless, the presented case of typical carcinoid with spindle cell component and mild to moderate cellular atypia has been classified according current WHO criteria as a typical carcinoid.
\end{abstract}

\section{Streszczenie}

Przedstawiono rzadki przypadek guza neuroendokrynnego o wysokim stopniu zróżnicowania oskrzela w wariancie wrzecionowatokomórkowym, częściowo pigmentowym u 42-letniej kobiety. Celem pracy opartej na opisie rzadkiego przypadku była dyskusja i przegląd piśmiennictwa na temat różnic kryteriów diagnostycznych guzów neuroendokrynnych w zakresie guzów oskrzelowo-płucnych i grasiczych oraz guzów przewodu pokarmowego. Istotnym czynnikiem różnicującym podejście do diagnozy jest różne postrzeganie i rola indeksu Ki67, który stopniowo staje się ważnym narzędziem diagnostycznym uzupełniającym tradycyjne kryteria histopatologiczne, takie jak aktywność mitotyczna i martwica w obrębie guza. Prezentowany przypadek uwidacznia pojawiające się wątpliwości diagnostyczne w przypadkach rzadkich wariantów rakowiaka i jego różnicowania głównie $z$ atypowym rakowiakiem.

\section{Introduction}

Neuroendocrine tumours (NETs) are well or moderately differentiated neoplasms, but neuroendocrine cancers (NEC) have significant metastatic potential. They comprise a large variety of rare and heterogeneous tumours with an estimated incidence of $3-5 / 100,000 /$ year. Around 25\% of NETs are localised in the bronchopulmonary system. Approximately $1-2 \%$ of all lung tumours are NETs $[1,2]$. The clinical presentation includes cough, haemoptysis, and obstructive pneumonia, but varies depending on site, size, and growth pattern. Less than 5\% of bronchopulmonary NETs exhibit hormonally related symptoms such as carcinoid syndrome, Cushing syndrome, acromegaly, and syndrome of inappropriate antidiuretic hormone secretion (SIADH) [3]. Lung neuroendocrine tumours are divided into four categories established by the World Health Organization (WHO 2004) classification. This sub-classification based on histopathological pattern divides NET/NEC into typical carcinoid (TC), atypical carcinoid (AC), large cell neuroendocrine carcinoma (LCNEC), and small cell carcinoma (SCLC), respectively. The reproducibility 
and prognostic efficacy WHO 2004 classification was intensely disputed until 2010. The WHO 2010 classification of neuroendocrine neoplasms diagnosis based on Ki67 proliferation assessment proved useful for prognosis exclusively for gastrointestinal tumours [4, 5]. Ki-67 is a discriminating factor and an important diagnostic criterion in differential diagnosis between NETs, but only for those of gastrointestinal localisation. Since precise diagnosis of NETs is currently based only on mitotic activity, Ki67 index and tumour necrosis, rare variants of NETs, especially spindle cell carcinoids with cellular atypia, could be potential pitfalls leading to diagnostic controversies or mistakes, especially with bronchopulmonary localisation.

\section{Case report}

Here, we present a case of a 42 -year-old female patient with a rare histopathological variant of bronchial NET. This study, with the use of human tissues, was in concordance with the ethical standards of the 2004 revision of the Declaration of Helsinki.

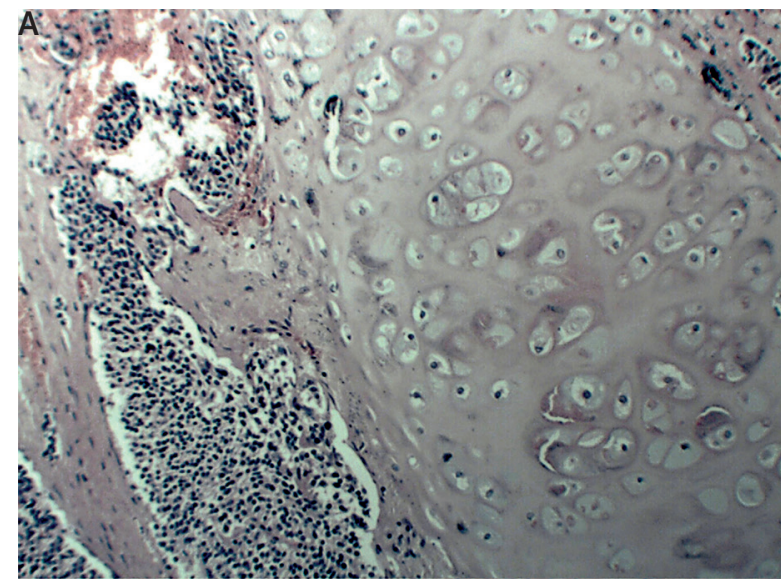

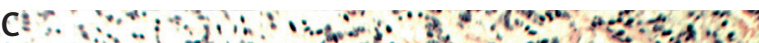

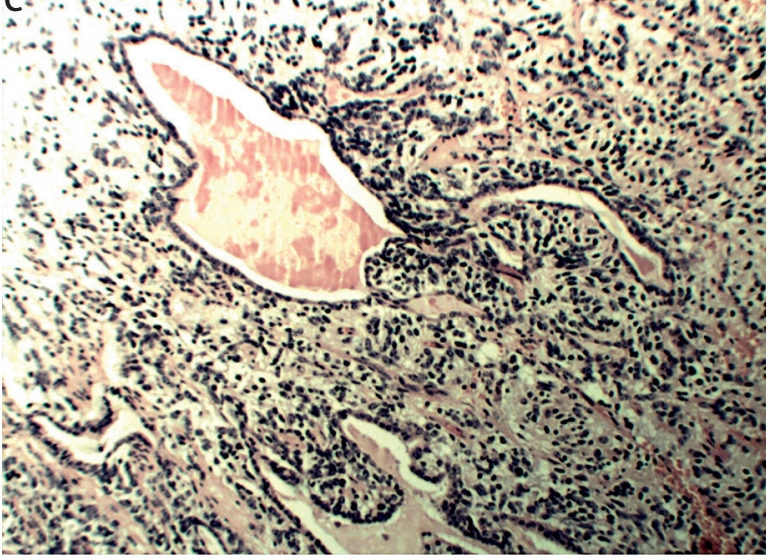

Figure 1. A - Bronchial cartilage infiltration by carcinoid ( $H+E$ stain, original magnification 10x), B - typical nested pattern of carcinoid ( $\mathrm{H}+\mathrm{E}$ stain, original magnification 40x), C - Macro-cystic pattern of tumour $(\mathrm{H}+\mathrm{E}$ stain, original magnification 10×), D - positive cytoplasmatic reaction for chromogranin A (original magnification 20x)

The patient was admitted to hospital due haemoptysis and cough with suspicion of a tumour-like mass at routine X-ray chest picture. Computer tomography and bronchoscopy confirmed the presence of endobronchial tumour; furthermore, this was confirmed by small biopsy as NET G1. The patient underwent typical left superior lobectomy with regional lymphadenectomy. Final pathological report described bronchial focal pigmented typical spindle cell carcinoid with metastases to regional lymphatic nodes. The case was staged as pT2aN1Mx according to the $7^{\text {th }}$ edition of TNM, issued by the American Joint Committee on Cancer (AJCC).

\section{Pathological findings}

Macroscopic evaluation of the surgical specimen showed a pulmonary lobe measuring $12 \mathrm{~cm} \times 7 \mathrm{~cm}$ $\times 4 \mathrm{~cm}$ with endobronchial et peribronchial tumour measuring $4.5 \mathrm{~cm}$ without macroscopic pleural effusion. The tumour was described as solid, soft and white without visible necrosis. The peribronchial lymph nodes were infiltrated by the tumour mass.
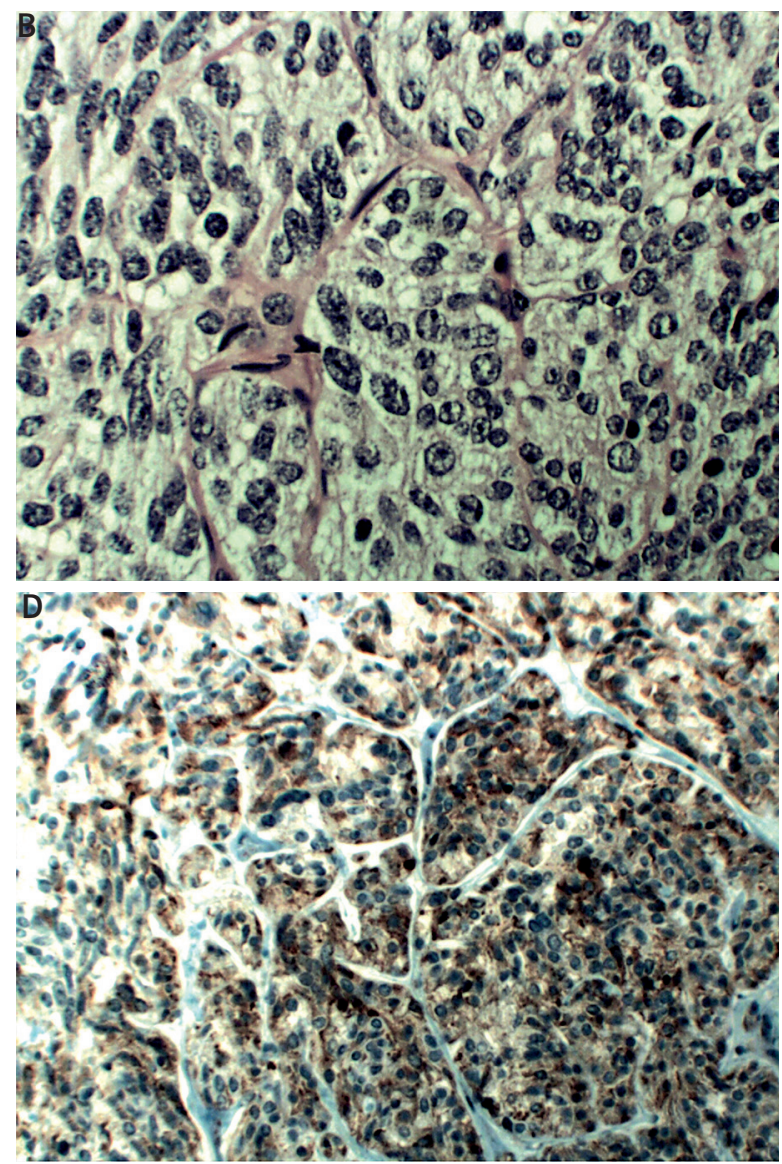

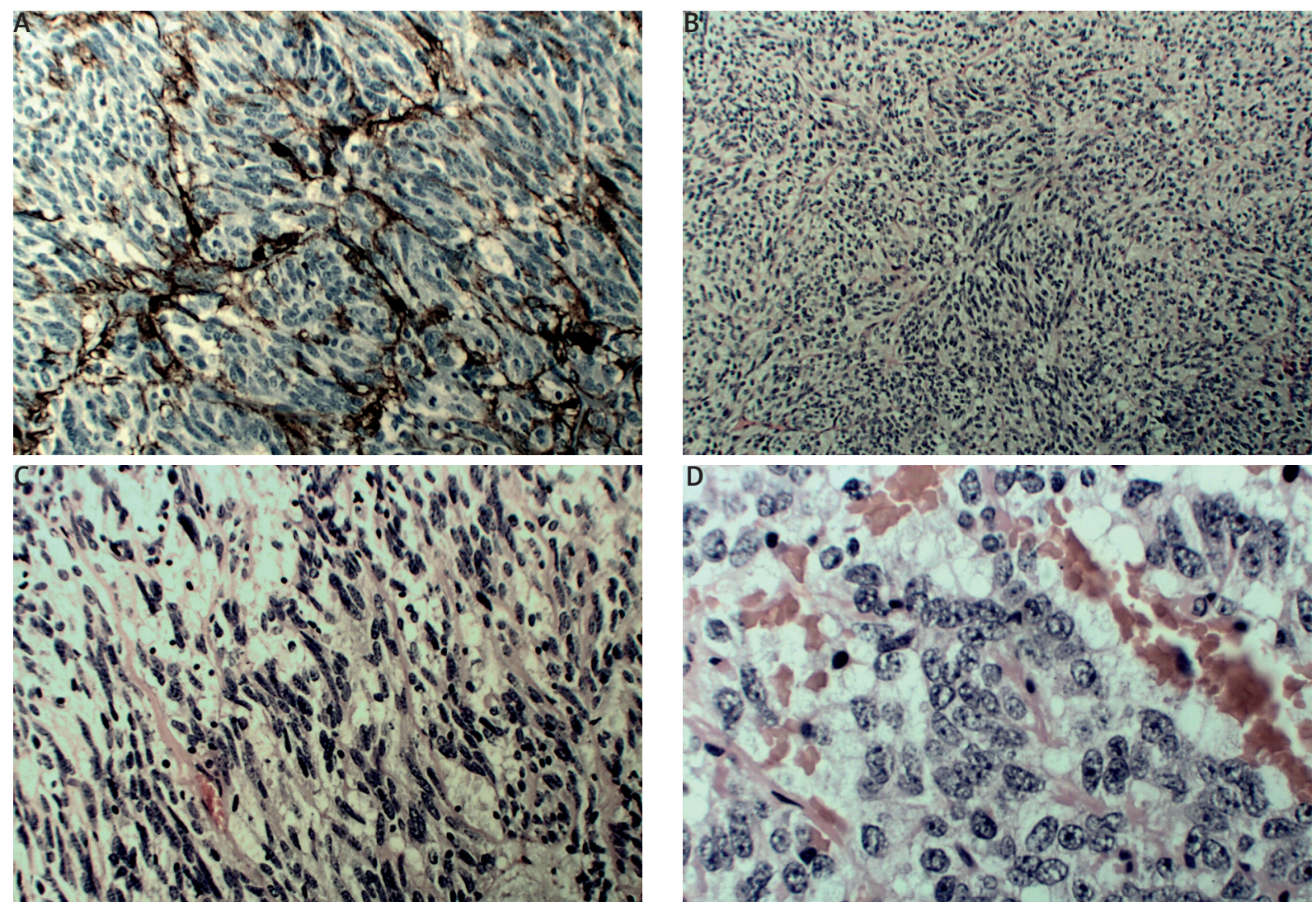

Figure 2. A - Fading of nests' texture in spindle cell foci (S-100 stein, original magnification 20x), B - storiform pattern of tumour $(\mathrm{H}+\mathrm{E}$ stain, original magnification 20x), C-D - cellular polymorphism and mild atypia of spindle and epithelioid cells $(H+$ E stain, original magnification $40 x)$

\section{Histopathological procedures}

The surgical specimen was fixed in $10 \%$ buffered formalin and then processed with routine histopathological procedures. Samples were then embedded in paraffin blocks and cut into $5 \mu \mathrm{m}$ slices. They were then stained routinely by haematoxylin-eosin, paS, mucicarmine, and alcian. Immunohistochemical analysis by Roche Benchmark Classic with the use of monoclonal antibodies Chromogranin A, Synaptophisin, S-100, HMB-45, CK AE1/3, Ki-67 was performed using a Ventana Ultra View Universal DAB Detection Kit (Ventana Medical Systems; Roche Group, Tucson, USA). As positive controls, tissues recommended by the manufacturers were used.

\section{Microscopic evaluation}

Microscopic evaluation showed a proliferation of epithelioid monomorphic cells with nested appearance, typical for neuroendocrine tumours. The tumour's borders had evident infiltrative character with destruction of the bronchial wall and bronchial cartilage (Figure 1). Other features of this tumour include spindle cell proliferation with low to moderate cellular atypia, low mitotic activity (maximum to $1 / 10 \mathrm{hpf}$ ) and, importantly, no tumour necrosis. A finding of typical neuroendocrine appearance in the form of irregular nests and fascicular texture with primitive plexiform pattern was subsequently seen (Figure 2). It is important to note that the mitotic index did not change in spindle cell parts of the tumour. A small part of the spindle cell component was distinguished by the presence of the amount of brown intracytoplasmatic pigment. Immunohistochemistry demonstrated strong expression of neuroendocrine markers such chromogranin A and synaptophysin and epithelial markers such CKAE1/3. S-100 showed persisting sustentacular cells and highlighted a nest-type texture of typical paraganglioma pattern. The Ki-67 percentage was measured as no more than 3-4\%. Differential diagnosis was confined mainly to atypical carcinoid. Here, according to the criteria of bronchial-thymus NETs, based on mitotic activity and the presence of necrosis, as well as optional Ki-67 status, the diagnosis was given as typical carcinoid with pigmented spindle cell variant.

\section{Discussion}

To date, complete resection with regional lymphadenectomy is the treatment of choice or gold standard treatment of NETs. Treatment of pulmonary carcinoid is a comprehensive modality focusing on surgery. Thus, 
accurate and timely preoperative and intraoperative pathological diagnoses are crucial. The progression-free survival period is substantially different in patients with TC and AC [6]. The AC, according to many researches and their many years of experience, appears to be the main factor that determines the risk of recurrence. The AC in comparison with TC has much worse disease-free survival rates for 3- as well 5-year periods [2, 4, 6-11]. According to Phan et al., assessment of the Ki-67 labelling index is not part of the classification of NETs of the lung and thymus (in contrast to gastroenteropancreatic NETs) [5]. Furthermore about Ki-67 meaning, limitations of Ki-67 and its influence to forecast a survival rate were discussed by Walts et al., in 2012. They were sceptical and concluded that the findings did not provide the best evidence for the routine use of the Ki-67 index to prognosticate overall short-term survival in patients with pulmonary carcinoid tumours [12]. In 2013 partially contradicting results were published by Warth et al. in a study about the usefulness of Ki-67 [13]. This inter-observer study performed by nine experienced pulmonary pathologists focused on analysis of h\&e NET slides and the Ki-67 index diagnosed manually and automatically with a software-based algorithm. Although the prognostic value needs further validation, Ki-67 might prospectively be considered a helpful diagnostic parameter to optimise the separation of TC from $\mathrm{AC}$, the authors concluded [13]. The tumour presented in our case demonstrates $1 \%$ mitotic activity (per $10 \mathrm{hpf}$ ), 3-4\% Ki-67 index, and lack of tumour necrosis. According to WHO criteria, it should be classified as TC, but we have a dilemma about how to deal with spindle cell components with atypia without non-increased proliferating index. It is worth mentioning that $2 \%$ mitotic activity indicates the change in the diagnosis on atypical carcinoid and clearly worsens the prognosis. This mathematically precise criterion as $1 \%$ mitotic activity and subsequently $2 \%$ or more for atypical carcinoid might be, as shown in this case, a cause of diagnostic dilemma due the very narrow diagnostic window. Furthermore, most cases in published works contain epithelioid cell variants of TC and AC. This poses the question: should we to use the same criteria for all histopathological types of carcinoid? The rarity of these histopathological types makes follow-up of these patients a real difficulty. Is over-diagnosis in these rare cases an incorrect choice? To date, the treatment of TC and AC is similar. Beyond that, the currently available interdisciplinary therapeutic options are local ablation, biotherapy (somatostatin analogues), or chemotherapy. New therapeutic options such as peptide receptor radionuclide therapy (PRRT) and molecularly targeted therapies have shown promising results and are under further evaluation $[1,5]$.

\section{Conclusions}

Currently available criteria for differential diagnosis between TC and AC are still disputed in literature, and partially opposing points of view have been pre- sented in this paper. In our opinion, this should incline medical professionals to search for similar gastrointestinal NETs in order to find consenting new diagnostic algorithms in future studies.

\section{References}

1. Hörsch D, Schmid KW, Anlauf M, et al. Neuroendocrine tumors of the bronchopulmonary system (typical and atypical carcinoid tumors): current strategies in diagnosis and treatment. Conclusions of an expert meeting February 2011 in Weimar, Germany. Oncol Res Treat 2014; 37: 266-76.

2. Naalsund A, Rostad H, Strøm EH, et al. Carcinoid lung tumors - incidence, treatment and outcomes: a populationbased study. Eur J Cardiothorac Surg 2011; 39: 565-9.

3. Gustafsson BI, Kidd M, Chan A, et al. Bronchopulmonary neuroendocrine tumors. Cancer 2008; 113: 5-21.

4. Rindi G, Klersy C, Inzani F, et al. Grading the neuroendocrine tumors of the lung: an evidence-based proposal. Endocr Relat Cancer 2013; 21: 1-16.

5. Phan AT, Oberg K, Choi J, et al.; North American NeuroendocrineTumor Society (NANETS). NANETS consensus guideline for the diagnosis and management of neuroendocrine tumors: well-differentiatedneuroendocrine tumors of the thorax (includes lung and thymus). Pancreas 2010; 39: 784-98.

6. Maurizi G, Ibrahim M, Andreetti C, et al. Long-term results after resection of bronchial carcinoid tumour: evaluation of survival and prognostic factors. Interact Cardiovasc Thorac Surg 2014 2014; 19: 239-44.

7. Wu BS, Hu Y, Sun J, et al. Analysis on the characteristics and prognosis of pulmonary neuroendocrine tumors. Asian Pac J Cancer Prev 2014; 15: 2205-10.

8. Cañizares MA, Matilla JM, Cueto A, et al. Atypical carcinoid tumours of the lung: prognostic factors and patterns of recurrence. Thorax 2014; 69: 648-53.

9. Aydin E, Yazici U, Gulgosteren M, et al. Long-term outcomes and prognostic factors of patients with surgically treated pulmonary carcinoid: our institutional experience with 104 patients. Eur J Cardiothorac Surg 2011; 39: 549-54.

10. Davini F, Gonfiotti A, Comin C, et al. Typical and atypical carcinoid tumours: 20-year experience with 89 patients. J Cardiovasc Surg (Torino) 2009; 50: 807-11.

11. Panko S, Karpitski A, Shelepen K, et al. Epidemiology, diagnostics and long-term overall survival of patients with non-small cell lung cancer in the Brest Region. Studia Medyczne 2013; 29: 203-12.

12. Walts AE, Ines D, Marchevsky AM. Limited role of Ki-67 proliferative index in predicting overall short-term survival in patients with typical and atypical pulmonary carcinoid tumors. Mod Pathol 2012; 25: 1258-64.

13. Warth A, Fink L, Fisseler-Eckhoff A. et al.; Pulmonary Pathology Working Group of the German Society of Pathology. Interobserver agreement of proliferation index (Ki-67) outperforms mitotic count in pulmonary carcinoids. Virchows Arch 2013; 462: 507-13.

\section{Address for correspondence:}

Piotr Lewitowicz MD, PhD

Jan Kochanowski University

ul. IX Wieków Kielc 19, 25-317 Kielce, Poland

Phone: +48 604420369

E-mail: lewitowicz@gmail.com 